http://dx.doi.org/10.4314/jae.v16i2.8

\title{
Physical Assets Ownership of Fisherfolk in Fishing Communities of Kainji Lake Nigeria: Implications for Climate Change
}

\author{
${ }^{1}$ Ifejika, P.I., ${ }^{2}$ Okunade, E.O., ${ }^{3}$ Ifejika, L.I. and ${ }^{4}$ Asadu, A.N \\ ${ }^{1}$ National Institute for Freshwater Fisheries Research \\ P.M.B 6006, New Bussa 913003. Niger State, Nigeria \\ Emails: ifejikaphilip@gmail.com \& ifejikaphilip@yahoo.com \\ ${ }^{2}$ Department of Agricultural Extension and Rural Development, \\ Ladoke Akintola University of Technology, Ogbomoso, Oyo State, Nigeria \\ ${ }^{3}$ Department of Home and Rural Economics, \\ Federal College of Freshwater Fisheries Technology, New-Bussa, Niger State. \\ ${ }^{4}$ Department of Agricultural Extension, University of Nigeria \\ Nsukka, Enugu State Nigeria
}

\begin{abstract}
A probe was carried out to ascertain fisherfolk ownership of physical assets for fisheries activities in fishing communities' vis-à-vis implication of climate change around Kainji Lake. Interview schedule was employed to generate primary data from 165 respondents in eleven fishing communities on western side of the lake and analysed with descriptive and inferential statistics. Information on personal characteristics revealed that most of the respondents were advanced in age, small scale artisan fisherfolk with many years of experience, self employed and married with children but had poor education. Physical assets owned fall into three categories of fishing asset (33.3\%), fish processing asset (41.7\%) and accessories (25\%). Conspicuous assets owned were fishing net, wooden canoe, hook \& line, fish drying net, improved banda and modified drum smoking kiln. Physical assets that use wood and fuelwood which impinged on climate change were fishing canoe, improved banda and modified drum smoking kiln. Correlates of improved banda and modified drum kiln were marital status and number of wives. It implies that marital family's ownership of fish smoking processing assets contributed to climate change problems through deforestation thereby causing desertification, soil erosion, destruction of ecosystem and weather variations with serious consequences on water bodies, fisheries, and livelihood in fishery around the lake. Worrisome is zero ownership of solar tent dryer which uses renewable energy of the sun and friendly to climate change adaptation. In view of prevailing evidence, adaptation to climate change is subject to modification of solar net drier to meet fish smoking needs. In alternative is exploration of biomass energy sources that is sustainable like rice husk for fish smoking as a mitigation strategy.
\end{abstract}


Key words: Nigeria, fisheries, assets, climate change.

\section{Introduction}

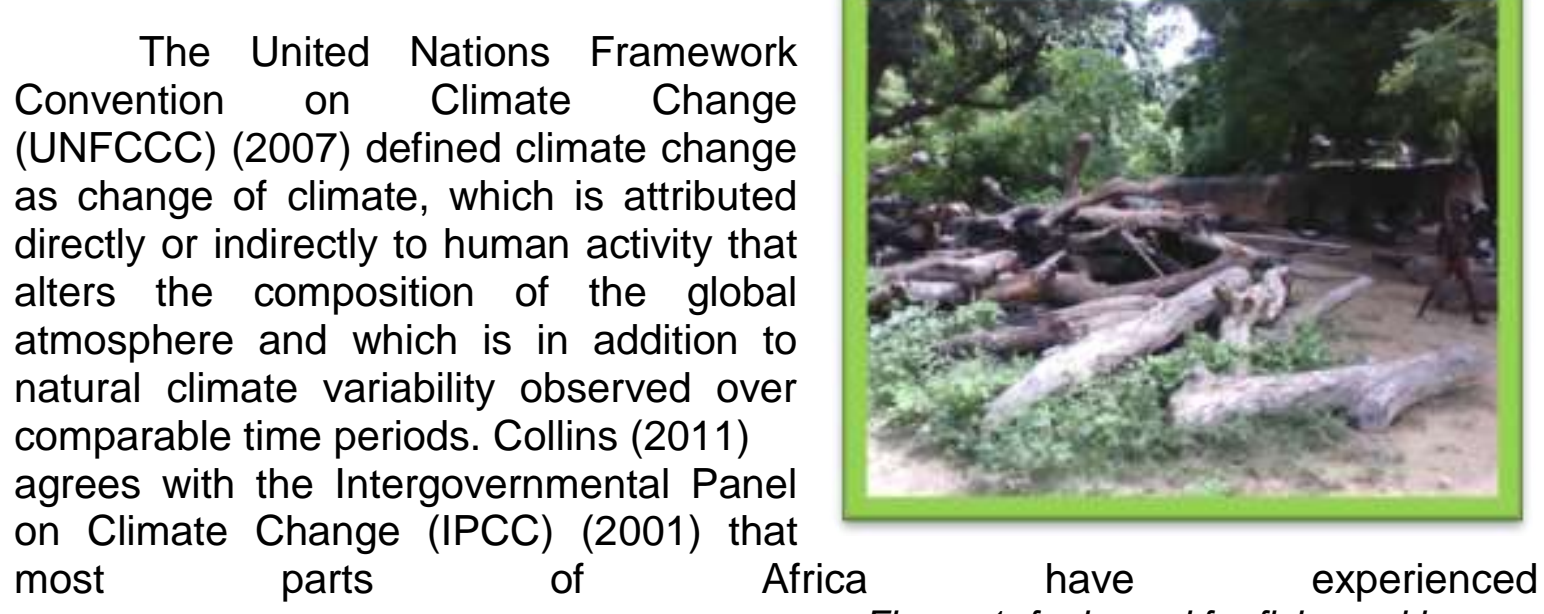

Figure 1: fuel wood for fish smoking

temperature increase (about $0.70^{\circ} \mathrm{C}$ ) in the last century, while Odjugo (2010) found temperature increase of $1.2^{\circ} \mathrm{C}$ in Port Harcourt (a coastal city) and $2^{\circ} \mathrm{C}$ in Nguru (a semi-arid city of Nigeria) between 1901 and 2005. Observed variations made African Ministerial Conference on Environment (AMCEN) (2011) to predict that in sub-Saharan Africa, 10 million people were affected by drought and 2 million by flooding, in many cases with near simultaneous episodes.

Unfortunately, rural people involved in agriculture have been blamed for escalating changes occurring in climate change which severely affects them. In the words of AMCEN (2011), agriculture is particularly vulnerable to climate change, but the sector directly and indirectly is also a major contributor to green house gas emissions and hence global warming. Buttressing the point was the World Bank (2003) report that Africa consumes the lowest energy amount of all the continents. In Nigeria, deforestation has been most severe; where more than 410,000

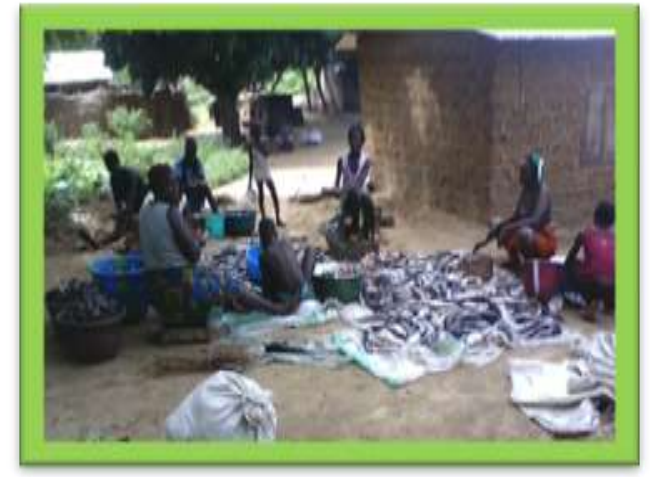
hectares of forest are lost to desertification annually (FAO, 2009). Confirming the fact was National Bureau of Statistics (NBS) (2009) study on type of fuel for cooking in Nigeria which revealed that almost $80 \%$ use wood, kerosene $(18.5 \%)$, electricity $(0.2 \%)$, gas $(0.6 \%)$, coal $(1.1 \%)$ and solar $(0 \%)$. It indicates high dependency on fuelwood than other energy sources by households in the country. Fuelwood consumption in Niger State was $89.3 \%$ in 2008 above the national levels signifying seriousness of cooking with fuelwood and it has negative impact on deforestation, 
Figure 2:Ffish processors preparing fish for smoking

desertification, ecosystem damage and harsh weather conditions with grave consequences on water bodies and fisheries.

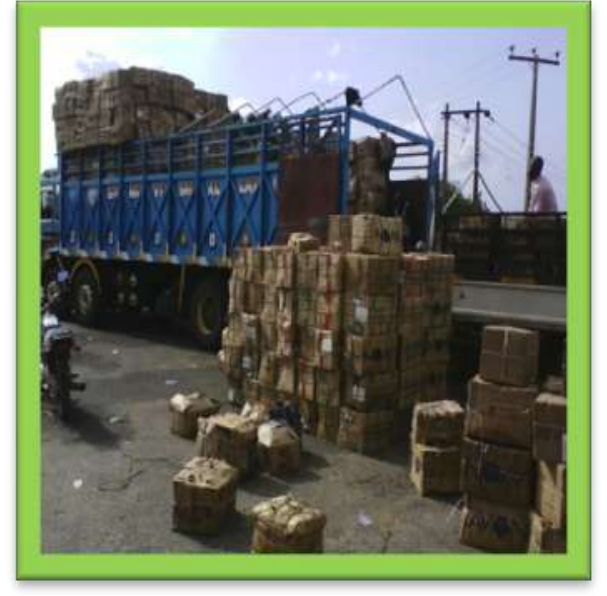

One issue to contend in fisheries is household ownership of physical assets. Household assets are defined broadly to include natural, physical, human, financial, public, and social capital as well as household valuables (Ellis, 2000). Winter et al., (2009) argued that the value and use of an asset depend not only on the quantity owned but also on the ownership status of the asset. In Kainji Lake, the total number of wooden canoes for fishing was 8,755 in 1995 and 4,820 in 2001 (Abiodun, 2003). Clue on magnitude of wood used for fish processing was provided by Olokor's (2003) study around Kainji Lake basin, which revealed that about $396,250 \mathrm{~kg}$ of wood costing $\$ 1,325,000.00$

Figure 3: lorry loading cartons of fish to Onitsha from kainji lake was used to smoke $189,883 \mathrm{~kg}$ of fish worth \#19, 273,600.00 annually, while the average fish processor consumes $16.45 \mathrm{~kg}$ of fuel wood per day or $7.5 \mathrm{~m}^{3}$ of forest wood compared to $0.46 \mathrm{ni}^{3}$ estimated for developing countries. On volume of fish smoked, Anthonio (1995) established that an average of $6,806.7 \mathrm{~kg}$ of smoked fish per month was transported from Kainji Lake basin to cities like Lagos, Ilorin, Kaduna, Enugu and the lake environs. Presently from New-Bussa axis, two truck load of lorries (911) transport an average of 307 cartons of smoke fish weekly to Ose market in Onitsha, Anambra State.

Volume of wood used for making canoe and smoking fish are indirectly contributing to observed decline in artisanal fish inland production which jeopardizes economy of fisherfolk, fish yield and consumption. For instance, Kainji lake basin data revealed a sharp decline on fish yield from 32,474 tonnes in 1995 to 13,361 tonnes in 2001 and 9,248 tonnes in 2004 (Abiodun, 2003; Abiodun and Niworu, 2004). Also, National artisanal inland fish production has declined from $38.7 \%$ to $37.7 \%$ between 2006 and 2010. These information buttresses the relationship between climate change and fisheries. Fagade (2010) enumerated consequences of climate change and global warming on Nigeria's fisheries to include increase in temperature, expansion of

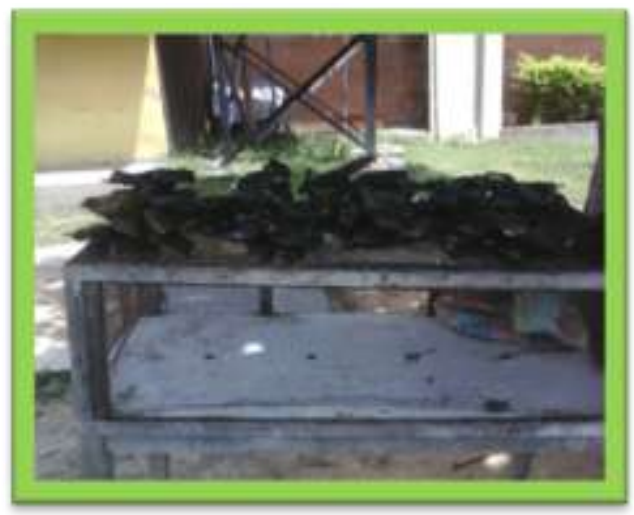

Figure 4: smoke fish in retail rack table 
the water volume, increase evaporation rate, precipitation, silt deposition during flooding, industrial effluents on aquatic organisms, salination of river waters from sea water rise. In aquaculture, it includes washing of ponds, suspended silt clogging on the gills of cultured fish species, pollution of water, high pond water temperature, decreased dissolved oxygen, $\mathrm{pH}$ and salinity of pond water. Hence, it is not surprising for artisanal fisher-folk to say that they need and seek information on weather conditions and rich fishing ground (Njoku, 2007; Okwu et al, 2011; Ifejika 2011). Equally, research has confirmed that fish farmers experience challenges on water quality management which is detrimental to fish growth in pond (Ifejika et al, 2009) and suffer flooding on earthen ponds (Adewuyi, 2009). Above premises prompted the need to determine fisher-folk ownership of physical assets among fisherfolk in Kainji Lake basin in relation to climate change. Outlined objectives for the study were to; ascertain personal characteristics of fisherfolk in fishing communities and to ascertain ownership of physical asset in fisheries activities.

\section{Methodology}

The study area is Lake Kainji situated between latitudes $9^{\circ} 50^{\prime}-10^{\circ} 57^{\prime}$ North and longitudes $4^{\circ} 25^{\prime}-4^{\circ} 45^{\prime}$ East is $136.8 \mathrm{~km}$ in length and $24.1 \mathrm{~km}$ maximum width. It is the first and largest manmade lake in Nigeria and popular for fishing, hydro-power and tourism since 1968. Niger and Kebbi States with five Local Government Areas border the lake in the west and east. The lake was stratified into west and east of which west was purposively selected for the study. From a list of 174 permanent fishing communities in western Kainji Lake, eleven were randomly chosen for the investigation namely: Malale, New-Bussa, Musawa, Monai, Yuna, Gwatanwara, Kaya, Sakakinjika, Yunawa, Tunga Angulu and Tunga Alhaji Ibrahim. Study population comprised of all residents in the eleven fishing communities from which 280 fisherfolk was purposively selected as the sample size. From the sample size of 280 , random sampling method was used to select 165 respondents for the study. Instrument for primary data collection was interview schedule through face to face interview. The interview schedule was face validated by experts in National Institute for Freshwater Fisheries Research (NIFFR), New-Bussa. Trained enumerators fluent in Hausa language were used to administer the interview schedule to respondents in the months of June and July, 2010. Descriptive and person product moment of correlation were used for data analysis. 


\section{Results and Discussions}

Only small proportions of respondents were youths (13.9\%) compared to majority in early adulthood (32.2\%), middle adulthood (44.6\%) and late adulthood $(9.7 \%)$. Finding on age suggest that about $50 \%$ of respondents are ageing. Dominant

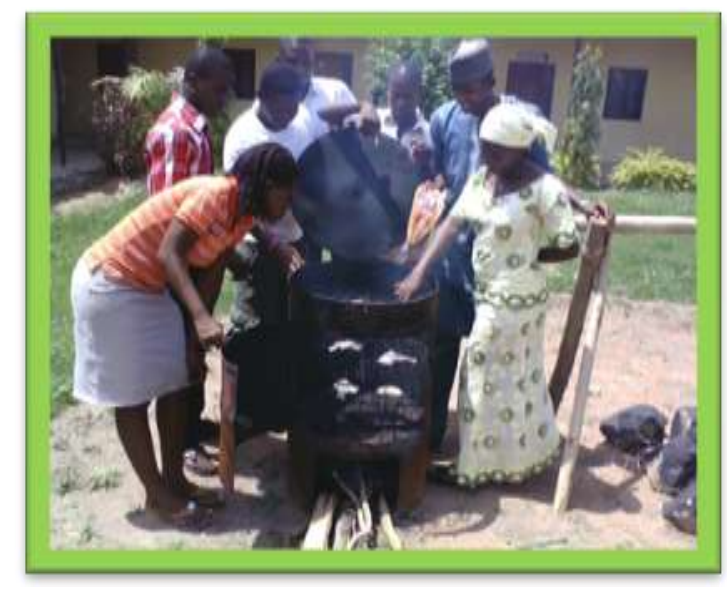

Figure 5: IT students demonstrating with drum kiln gender among fisherfolk was male which account for 3 out of 4 respondents. Equally, most respondents (80\%) were married and practice polygamy (55\%) over monogamy (45.5\%). It suggests most respondents have family responsibilities. Data on years of schooling revealed that vast majority $(77 \%)$ were considered to be illiterate, lacking the ability to read and write which is an impediment to acceptance of new innovations and practices. Almost all respondents were self employed but fishers out number fish processors and fish marketers. Interestingly, respondents have acquired many years of experience in their fisheries activities through which they gain skills and know-how for survival in livelihood activities and climate change adaptation and mitigation strategies. 
TABLE 1

Fisherfolk selected personal characteristics

\begin{tabular}{|c|c|c|}
\hline Age & Frequency & $\%$ \\
\hline $15-24$ & 23 & 13.9 \\
\hline $25-34$ & 53 & 32.2 \\
\hline $35-44$ & 45 & 27.2 \\
\hline $45-54$ & 29 & 17.6 \\
\hline $55-64$ & 13 & 8.5 \\
\hline 65 above & 2 & 1.2 \\
\hline \multicolumn{3}{|l|}{ Gender } \\
\hline Male & 128 & 77.6 \\
\hline Female & 37 & 22.4 \\
\hline \multicolumn{3}{|l|}{ Marital Status } \\
\hline Single & 26 & 15.8 \\
\hline Widow & 2 & 1.2 \\
\hline Widower & 3 & 1.8 \\
\hline Married & 132 & 80.0 \\
\hline \multicolumn{3}{|l|}{ No of wives } \\
\hline 1 & 60 & 45.5 \\
\hline 2 & 46 & 34.8 \\
\hline 3 & 22 & 16.7 \\
\hline \multicolumn{3}{|c|}{ Education (Years of Schooling) } \\
\hline 0 & 64 & 38.8 \\
\hline $1-6$ & 49 & 29.7 \\
\hline $7-12$ & 46 & 27.9 \\
\hline $13-18$ & 6 & 3.6 \\
\hline \multicolumn{3}{|c|}{ Primary occupation } \\
\hline Fishers & 108 & 65.5 \\
\hline Fish processing & 29 & 17.5 \\
\hline Fish marketing & 28 & 17.0 \\
\hline \multicolumn{3}{|c|}{ Employment status } \\
\hline Self-employed & 160 & 97.0 \\
\hline Paid employee & 5 & 3.0 \\
\hline \multicolumn{3}{|l|}{ Experience } \\
\hline $1-10$ & 51 & 30.9 \\
\hline $11-20$ & 73 & 44.3 \\
\hline $21-30$ & 35 & 21.2 \\
\hline 31 above & 6 & 3.6 \\
\hline
\end{tabular}


Entries in Table 2 was on respondents' ownership of physical asset for fisheries activities. The twelve assets examined fall into three categories; fishing assets (33.3\%), fish processing (41.7\%) and accessories (25\%). Dominant fishing assets owned were fishing net $(78.2 \%)$ and fishing canoe (64.8\%). On fishing assets, only fishing canoe has direct negative effect on climate change through cutting of wood with serious consequences on deforestation. Fishing boat made of cheap fibre or plastic will reduce the cutting of wood for canoe construction and its negative impact on climate change and fish

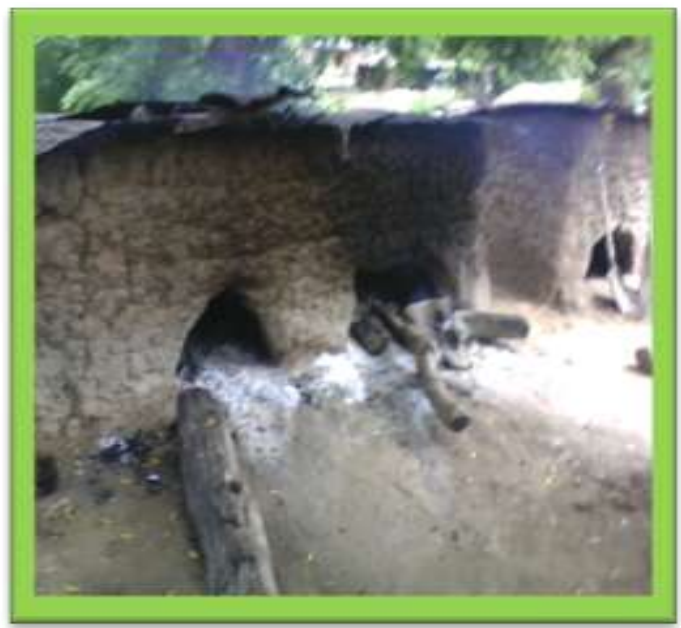

Figure 6: improve banda for fish smoking habitat in water bodies in the area.

Conspicuous fish processing assets respondents owned were fish drying net (87. $9 \%)$, improved banda (77.6\%) and modified drum smoking kiln (16.4\%). Only improved banda and modified drum smoking kiln utilises fuelwood for fish smoking with grave consequences on climate change which indirectly affect water bodies, fisheries and livelihood of fisherfolk in the area. Eyo (1997) found that $73 \%$ of smoked fish by fish processors and marketers use traditional banda to burn wood. While Olokor (2003) revealed that $396,250 \mathrm{~kg}$ of wood were used to smoke $189,883 \mathrm{~kg}$ of fish by fish processors in the lake basin. Existing evidences buttress FAO (2009) report that the annual deforestation rate has increased from $2.7 \%$ between $1990-2000$ to $3.3 \%$ in $2000-2005$, and currently less than $12.2 \%$ of the country land is forested.

Fish drying net and solar tent dryer are assets for fish processing that use sun energy, environmental friendly and pose no harm to climate change (see figure 8). But worrisome is $0 \%$ ownership of solar tent fish dryer among respondents in the area. Earlier studies supporting finding on rejection of solar tent fish drier among fisherfolk in Kainji lake basin were Sule et al., (2007) and Ifejika

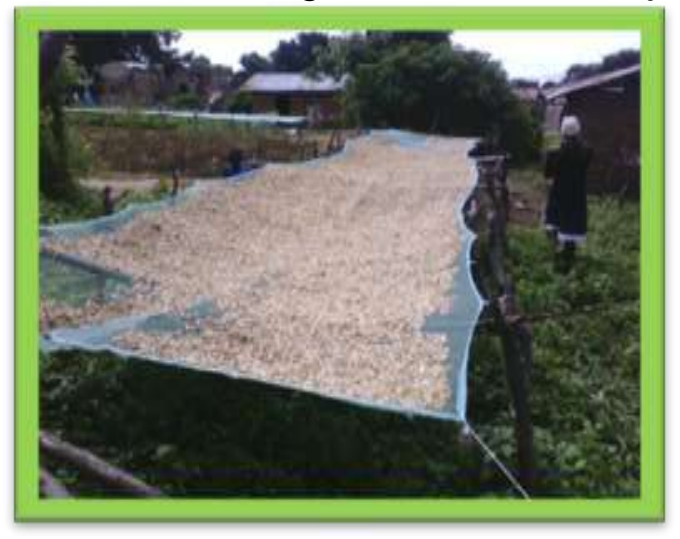

Figure 7: Clupeid spread on net for sun dry (2011). But Souness (1988) provided insight for the rejection been that solar drying has long been recognised as a significant cause of loss in dried fish as a result of control over the final moisture content of the product and prolonged drying. As such, no drier designed has been commercially successful in South Asia. But fish drying net is ideal for clupeids (small fish) which is spread on net and exposed to sun energy for water evaporation and dehydration as demonstrated in Figure 7. 
Ownership of other physical assets like fishing nets, speed engine boat, hook \& line, deep freezer and all accessories constitute no threat to climate change.

Table 2

Fisherfolk ownership of physical assets for fisheries activities

\begin{tabular}{lcc}
\hline Fishery Physical assets & Frequency & $\%$ \\
\hline Fishing net (Fishing) & 129 & 78.2 \\
Hook \& line & 102 & 61.8 \\
Engine boat & 45 & 27.3 \\
Canoe & 107 & 64.8 \\
Solar tent (Processing) & 0 & 0.0 \\
Drum smoking kiln & 27 & 16.4 \\
Improve Banda & 128 & 77.6 \\
Deep freezer & 8 & 4.8 \\
Drying net & 145 & 87.9 \\
Weighing scale (Accessories) & 80 & 48.5 \\
Basin/plastic & 155 & 93.9 \\
Others (cutlass \& files) & 65 & 31.4
\end{tabular}

Source: Computer generated from field data, 2010. (multiple response)

Table 3 result reveals that number of wives correlates with ownership of modified drum kiln $\left(p=.028\right.$ and $\left.r^{2}=.151\right)$ while improved banda ownership $(p=.000$ and $\left.r^{2}=.290\right)$ was positively associated with marital status. Age, gender, occupation, education and experience had negative and weak correlation with ownership of fish processing assets analysed. Validating the result was Onemolease and Erie (2006) founding on positive influence of marital status ( $\mathrm{rho}=0.682$ ) and household size (rho $=0.791$ ) on women participation in artisanal fishery activities of smoking and marketing in Ondo and Delta States. This was further strengthen by Mdaihli and Alamu (1994) and Alfred-Ockiya (2000) studies which established that women dominated fish processing and marketing activities. Positive association of marital issues suggests that family households particularly women, mostly acquire fish processing asset of modified drum smoking kiln and improve banda among respondents. It implies that most of the fish processing asset owners were women that use it for fish smoking in fisheries livelihood. Therefore, family members' involved in fish smoking contributes to problem of climate change around Kainji lake basin which indirectly impinges on their fisheries livelihood. It calls for exploration of alternative fish smoking methods that uses sustainable energy like rice husk for climate change mitigation and adaptation strategy in fishing communities around the lake basin. 
TABLE 3

Correlates of ownership of fish processing asset of drum kiln and banda

\begin{tabular}{|c|c|c|c|c|c|c|c|}
\hline Variables & Age & gender & $\begin{array}{l}\text { Marital } \\
\text { status }\end{array}$ & $\begin{array}{l}\text { No of } \\
\text { wives }\end{array}$ & Occupation & Education & Experience \\
\hline \multicolumn{8}{|l|}{ Drum } \\
\hline kiln & & & & & & & \\
\hline$r^{2}$ & .107 & -.041 & .078 & $.151^{*}$ & .045 & -017 & .127 \\
\hline $\begin{array}{l}\text { p-value } \\
\text { Banda }\end{array}$ & .086 & .299 & .165 & .028 & .285 & .414 & .052 \\
\hline$r^{2}$ & .119 & .115 & .290 ** & .089 & .077 & .009 & .080 \\
\hline p-value & .063 & .071 & .000 & .127 & .183 & .453 & .154 \\
\hline
\end{tabular}

Source: computer generated from field data (2010)

Significant at ${ }^{\star} 0.005 \&{ }^{* *} 0.001$ levels.

\section{Conclusion and Recommendation}

Evidence from the study confirm that ownership of certain physical asset for fishing and fish processing has direct and indirect bearing on climate change with consequences on inland water bodies, fish and livelihood of fiherfolk in fsheries. The identified physical assets are fishing canoes, improved banda and modified drum smoking kiln that use fuel wood. Correlates of fish processing assets of improved banda and modified drum smoking kiln were marital status and number of wives. Worrisome is zero ownership of solar that is environmental friendly for climate adaptation. Climate change adaptation and mitigation should exploration alternative fish smoking methods that uses sustainable energy like rice husk or modification of solar tent fish dryer to meet fish processing needs of fisherfolk. Equally important is awareness creation and training of fisherfolk on eminent hazards of acquiring certain physical assets that negatively contribute to climate change in the area. 


\section{References}

Abiodun, J A (2003). Evaluation of fisheries catch trend on Lake Kainji, in Nigeria, 1995- 2001. Journal of applied sciences \& environmental management, Vol. 7, (2 ). Pp 9-13

Abiobun, J.A. and Niworu, A.M. (2004). Fisheries Statistical Bulletin Kainji Lake, Nigeria. ISSN: 1119-1449. Kainji Lake fisheries management and conservation unit. technical report Series 23. pp 1-23.

Adewuyi, S.A. (2009). Technical efficiency of fish farms in Ogun State, Nigeria: A stochastic production frontier approach. Nigerian Journal of fisheries Vol. 6 (1\&2). pp123- 129.

Alfred-Ockiya, J.F. (2000). Socio-economic activities of women in artisanal fisheries of the Niger Delta, Nigeria. Aquafield, (1) 30-35.

AMCEN (2011). Addressing climate change challenges in Africa: A practical guide towards sustainable development.

Anthonio, Q.B.O. (1995). Fish marketing survey in the Kainji Lake basin. Report prepared for the Nigeria-German (GTZ) Kainji Lake fisheries promotion project. 56p.

Collins, J. M., (2011) Temperature variability over Africa. Journal of climate. Early online release, doi, 10.1175/2011JCLI3753.1. Accessed on 81/2012

Eyo, A.A. (1997). Post harvest losses in the fisheries of Kainji Lake. Technical report series 5: Nigeria-German Kainji Lake fisheries promotion project. pp1-60

Ellis, F. (2000). Rural Livelihoods and diversity in developing countries. Oxford: Oxford University Press.

Fagade, S.O (2010). Climate Change: Implications for fisheries and coastal aquaculture. Keynote Address delivered on 25th annual conference, fisheries society of Nigeria, held at Administrative Staff College of Nigeria, Badagry, Lagos State, Nigeria, $26^{\text {th }}$ October, 2010.

FAO, 2009: World's Forests 2007: Food and Agriculture Organization of the United Nations Rome. (http://www.fao.org/docrep/011/i0350e/i0350e00.htm)

Ifejika, P.I. (2011). Preliminary evaluation of mobile phone usage among fisher-folk for mainstreaming fisheries extension in Kainji Lake Nigeria. Master of philosophy thesis, dept of agricultural extension and rural development department, Ladoke Akintola University of Technology, Ogbomoso, Oyo State, Nigeria. pp 41-70. 
Ifejika, P.I., Oladosu, I.O., Nwosu, I., Ayanda, J.O., Asadu, A.N., and Olowosegun, T. (2009). Influence of information sources on aquaculture technologies utilisation among fish farmers in Oyo State, Nigeria. Nigerian journal of fisheries vol. 6 (1\&2). pp 116- 122.

IPCC. (2007). Climate change 2007: synthesis report. Contribution of working groups I, II and III to the fourth assessment report of the intergovernmental panel on climate change [Core Writing Team, Pachauri RK and Reisinger A eds]. IPCC, Geneva, Switzerland.

Mdaihli, M and Alamu, S.O. (1994). Socio-economic survey of women in artisanal fisheries in Kainji Lake Area: A Case Study of Wawu. NIFFR Annual Report. pp 1.66-170

National Bureau of Statistics (2009). Social Statistics in Nigeria. $43-46 p$

Njoku, I.F. (2004). The information needs and information-seeking behaviour of fishermen in Lagos State, Nigeria. The international information \& library review. pp36, 297-307.

Odjugo, A. O.( 2010). Regional evidence of climate change in Nigeria; Journal of geography and regional

Okwu,O.J., Yahaya, M.A. and Obinne, C.P.O. (2011). Analysis of artisanal fisher folk information needs and accessibility in Benue State, Nigeria. Asian journal of agricultural sciences 3(5): 408-413

Olokor, J.O. (2003). Cost of fuelwood for fish smoking around Kanji Lake and economic prospects of the kanji solar tent fish dryer. Proceedings of fisheries society of Nigeria (FISON) .pp 105-109.

Onemolease, E.A. and Erie, G. (2006). Characteristics and role of women in artisanal fishery in selected Riverine communities in South-Western Nigeria. Global approaches to extension practice, vol.2, no.2. pp19-26.

Souness, R. (1988). Development off a rice husk-fired furnace and its application to fish drying. Paper presented at the seventh session of the INDOPACIFIC fishery commission working party on fish technology and marketing, Bangkok, Thailand, 19-22 April, 1988. FAO Fisheries Report No. 401 Supplement, F11V/401(SUPPL.). pp 160-167.

Sule, A.M., Olowosegun, T., Sanni, A.O. and Bwala, R.I. (2007). Socio-economic variables affecting the adoption of solar tent technology in kainji lake basin. Journal of Arid Zone Fisheries, vol.3, no.2, pp45-55.

UNFCCC. 2007. Investment and financial flows to address climate change. United Nations framework convention on climate change, Bonn, Germany. 272 p. ISBN 92-9219-042-3. UNFCCC. nd. Adaptation Private Sector Initiative. http://unfccc.int/adaptation/nairobi work programme/knowledge resources and publications/items/4623.php 
Winters, P., Davis, B., Carletto, G., Covarrubias, K., Quinones, E.J., Zezza, A., Azzarri, C., and Stamoulis, K. Assets, activities and rural income generation: evidence from a multicountry analysis. World Development Vol. 37, No. 9, pp. 1435-1452

World Bank, 2003. World Development Indicators 2003. Washington DC, USA: The World Bank 